\title{
Analysis of influence of structure on mechanical properties of AISiMg aluminium alloy processed by ECAP
}

Greger Miroslav, doc. Ing. CSc., Faculty of Metallurgy and Materials Engineering, VŠB-Technical University Ostrava Widomská Milena, Ing. Ph.D. MBA, VŠB-Technical University Ostrava

Microstructure and texture development of an AISiMg alloy during equal channel angular pressing (ECAP) was investigated and correlated with the mechanical properties. The micro-structure was effectively refined by ECAP, and the original fibre texture of the extruded aluminium alloy was disintegrated and a new texture was gradually developed by repetitive ECAP pressing. After 6 ECAP passes following the route Bc, the yield stress was lower than that of the asextruded aluminium alloy, indicating that the texture softening was dominant over the strengthening due to grain refinement. Cross-section of original samples was $\phi 12 \mathrm{~mm}$ and their length was $80 \mathrm{~mm}$. Deformation forces were measured during extrusion, resistance to deformation was calculated and deformation speed was determined approximately. Analysis of structure was made with use of light microscopy, TEM and SEM. Mechanical properties of the samples after extrusion were determined by tensile test and by the so called penetration test.

Keywords: micro-structures, properties, aluminium alloy, ECAP

Acknowledgements

The works were realised under support of the Czech Ministry of Education - project VS MSM 6198910013 and project GA Czech Republic No. 106/09/1598.

\section{References}

[1] CONRAD, H., NARAYAN, J. On the grain size softening in nanocrystalline materials. Scripta Materiallia, 2000, vol. 42, no. 11, pp. 1025-1030.

[2] RAJASEKHARA, S. et al. Micro-structure evolution in nano/submicron grained stainless steel. In $6^{\text {th }}$ European Stainless Steel Conference: Helsinki, 2008, pp. 505-510.

[3] KUMAR, K.S., SWYGENHOVEN, H.V., SURESH, S. Mechanical behavior of nanocrystalline metals and alloys. Acta Materialia, 2003, vol.51, p. 5743-5774.

[4] POORTMANS, S., VERLINDEN, B. Mechanical properties of fine-grained AA1050 after ECAP. Materials Science Forum. 2006, vol. 503-504, p. 847-852.

[5] CHINH, N.Q et al. Grain boundary sliding as a significant mechanism of low temperature plastic deformation in ECAP aluminium. Materials Science Forum. 2006, vol. 503-504, p. 1001-1006.

[6] GREGER, M. et al. Possibilities of aluminium extrusion with use of a the ECAP method, Proceedings of $9^{\text {th }}$ International conference Aluminium in Transport 2003. Institute of Non-Ferrous Metals, Cracow-Tomaszowice 2003, 165169.

[7] GREGER, M., KANDER, L., KUŘETOVÁ, B. Plastic forming of ECAP processed EN AW 6082 aluminium alloy. University Review. Alexander Dubček University of Trenčín, 2008, Vol. 2, No.3, p. 84-90. 